\title{
Water Molecular Adsorption on the Low-Index Pt Surface: A Density Functional Study
}

\author{
Wahyu Tri Cahyanto*, Aris Haryadi, Sunardi, Abdul Basit, and Yulin Elina
}

\author{
Department of Physics, Universitas Jenderal Soedirman, \\ J. Dr. Soeparno, Karangwangkal, Purwokerto 53123, Indonesia
}

Received April 18, 2017; Accepted November 24, 2017

\begin{abstract}
We report the different way to explain the nature of water molecule $\left(\mathrm{H}_{2} \mathrm{O}\right)$ adsorption on the platinum (Pt) surfaces with low Miller index, i.e., (100), (110) and (111). Here, we perform periodic density functional theory (DFT) calculations to analyze the correlation between water-surface bonding strength and the observed charge transfer occurring in the systems. The results show that $\mathrm{Pt}_{-} \mathrm{H}_{2} \mathrm{O}$ interaction strength at the most stable adsorption sites, i.e., the atop site for each surfaces, follows the order of $\mathrm{H}_{2} \mathrm{O} / \mathrm{Pt}(110)>\mathrm{H}_{2} \mathrm{O} / \mathrm{Pt}(100)>\mathrm{H}_{2} \mathrm{O} / \mathrm{Pt}(111)$. This order has the same pattern with the order of observed charge transfer contributed to the bonding formation. The differences in adsorption geometrical structures in these three surfaces are suggested to responsible for the order of bond strength since Coulomb interaction plays dominant roles in our electrostatic model. Furthermore, $\mathrm{H}_{2} \mathrm{O}-\mathrm{Pt}$ interaction mechanism, which occurs through water $3 a_{1}$ orbital releasing electron density (charge) followed by Pt-O bonding formation, is clarified.
\end{abstract}

Keywords: $\mathrm{H}_{2} \mathrm{O}$ adsorption; low Miller index; Pt surface; DFT; charge transfer

ABSTRAK

Kami melaporkan cara yang berbeda dalam menjelaskan adsorpsi molekul air $\left(\mathrm{H}_{2} \mathrm{O}\right)$ pada permukaan platina (Pt) dengan indeks-indeks Miller rendah, yaitu (100), (110), dan (111). Pada riset ini digunakan perhitunganperhitungan berbasis teori fungsional kerapatan (DFT) untuk menganalisis hubungan antara kekuatan ikatan antara air-permukaan Pt dan transfer muatan yang terjadi di dalam sistem. Hasil-hasil menunjukkan bahwa kekuatan interaksi Pt- $\mathrm{H}_{2} \mathrm{O}$ pada situs-situs adsorpsi paling stabil, yaitu pada situs top untuk semua model permukaan, mengikuti urutan $\mathrm{H}_{2} \mathrm{O} / \mathrm{Pt}(110)>\mathrm{H}_{2} \mathrm{O} / \mathrm{Pt}(100)>\mathrm{H}_{2} \mathrm{O} / \mathrm{Pt}(111)$. Urutan ini memiliki pola yang sama dengan urutan besar transfer muatan yang berkontribusi pada pembentukan ikatan. Perbedaan dalam struktur geometri adsorpsi pada ketiga model permukaan diduga bertanggung jawab pada urutan kekuatan ikatan, karena interaksi Coulomb memainkan peran yang dominan pada model elektrostatika dari adsorpsi. Selanjutnya, mekanisme interaksi antara $\mathrm{H}_{2} \mathrm{O}$-Pt yang terjadi melalui pelepasan rapat elektron (muatan) oleh orbital $3 \mathrm{a}_{1}$ dari molekul air diikuti pembentukan ikatan Pt-O berhasil diklarifikasi.

Kata Kunci: adsorpsi $\mathrm{H}_{2} \mathrm{O}$; indeks Miller rendah; permukaan Pt; DFT; transfer muatan

\section{INTRODUCTION}

Water on metal surfaces is the most common system that allows countless applications in nature including many chemical processes, such as electrochemistry [1], catalysis [2], and also corrosion at metals [3]. Among these important aspects, we are turning our attention to catalyst systems, especially in direct methanol fuel cell (DMFC) technologies. In the DMFCs, interactions of $\mathrm{H}_{2} \mathrm{O}$ with metal surfaces are observed at both the anode and the cathode. These are related to either methanol electrooxidation reaction (MOR) at the anode or the product of oxygen electroreduction reaction (ORR) at the cathode [4-5]. Here, the water-surface interaction at the anode is more

* Corresponding author.

Email address : wahyu.cahyanto@unsoed.ac.id interesting because the water acts as a solvent for methanol fuel or simply as reactants, while the water at the cathode acts as unused products. Therefore, researches on the modification of the anode catalyst materials have been of great interests in past few decades. Of the modified catalysts, Pt [6] and Pt-based catalysts remain the most preferred since they provide optimal results for DMFCs performance. The said modified Pt-based catalysts described in our literature reviews involve the addition of other metals, e.g. Pt-Ru [7-8], Pt-Co [9], Pt-Cu [10], Pt-Mo [11], Pt-Pd [12], PtRu-Mo [13] - and even Pt-Ru-O-Ir catalyst systems [14]. However, we will not discuss in detail the processes in DMFCs, but we focus on the fundamental

Wahyu Tri Cahyanto et al. 
part of $\mathrm{H}_{2} \mathrm{O}-\mathrm{Pt}$ systems as one of the reaction steps in $\mathrm{MOR}$, in a scientific perspective.

In modern surface science, the presence of $\mathrm{H}_{2} \mathrm{O}$ on metal surfaces has been experimentally studied under extremely clean ultra-high vacuum (UHV) conditions, at least for the past 3.5 decades [15-16]. These long-term studies aimed to understand how the $\mathrm{H}_{2} \mathrm{O}$ molecule binds to the metal surface, since the physical and chemical properties of this typical interaction are determined by the geometric structure. Therefore, the understanding of these interactions at the atomic level is used to leverage the right technological application. In conjunction with the DMFC technologies, where the MOR also involves the interaction between $\mathrm{H}_{2} \mathrm{O}$ and catalyst metal surfaces, the nature of this interaction is considered necessary. Moreover, the interaction known as adsorption of water molecules on the metal surface is also one of the steps for the overall reaction of MOR [6]. While the mechanism of adsorption of methanol and its derived fragments on $\mathrm{Pt}$ and $\mathrm{Pt}$ alloy surfaces was explained in our earlier work [17-20], we now come to $\mathrm{H}_{2} \mathrm{O}-\mathrm{Pt}$ systems. In this case, the existence of $\mathrm{H}_{2} \mathrm{O}$ molecules on Pt surfaces was confirmed by several experiments using different techniques, such as atom superposition and electron delocalization (ASED) [21], low energy electron diffraction (LEED) [22], or scanning tunneling microscopy (STM) [23]. Theoretical studies have also extended the investigation of water at various Pt-surface models in order to obtain the fundamental correlation between surface geometry and electronic structure and reactivity [24-27]. From our literature surveys, we have not yet found any analyses of $\mathrm{H}_{2} \mathrm{O}-\mathrm{Pt}$ bonding on the basis of charge transfer in the adsorption process. Thus, in this paper we elaborate the new insight in analyzing adsorption mechanism of $\mathrm{H}_{2} \mathrm{O}$ on $\mathrm{Pt}$ surfaces by correlating the adsorption energy and the charge transfer.

\section{EXPERIMENTAL SECTION}

\section{Materials}

The present study is based on computer-assisted quantum simulations to model water adsorption on $\mathrm{Pt}$ catalysts in direct methanol fuel cells. The materials used are thus in the form of virtual atomic Pt-forming surface systems, as shown in Fig. 1, and virtual water molecules.

\section{Instrumentation}

The instruments used in this study are four computers. The hardware specifications are octa-core computers with Core i7 processors and 16 GB of RAM. The main software for the calculation is the licensed
Vienna ab initio Simulation Package (VASP). To visualize the calculation results, we used Gnuplot to draw the density of states (DOS), VESTA to visualize the charge distribution, and Bader analysis to perform the charge numerically.

\section{Procedure}

\section{Catalyst surface models}

The models for $\mathrm{H}_{2} \mathrm{O}$ adsorption are flat catalyst surfaces with low Miller indices of Pt (100), (110) and (111) due to their stabilities and reactivities in catalyzing methanol electrooxidation reaction in DMFC operations. These indices are generated by slicing a slab of bulk $\mathrm{Pt}$ and the lattice parameter is taken from the experimental data of $3.92 \AA$ [28]. Supercells with a 3-layer fcc metal slab and large enough of $\sim 15 \AA$ of vacuum being kept constant, are used to model the metal surfaces. The three layers of surface models are based on the acceptable preliminary calculation, which are sufficient enough to represent the bulk $\mathrm{Pt}$ in real catalyst systems. The slabs are optimized by relaxing the first two layers while all atoms in the bottom most layer are fixed representing bulk Pt. The criterion for convergence due to structure relaxation is determined by the Hellmann-Feynman forces acting on whole atoms are less than $0.05 \mathrm{eV} / \AA$. Then, the $3 \times 3$ unit cells of surfaces are employed, which refer to $\sim 1 / 9 \mathrm{ML}$ $\mathrm{H}_{2} \mathrm{O}$ coverage with respect to the number of surface atoms. Fig. 1 represents the surface systems. All possible adsorption sites for each Miller index of $\mathrm{Pt}$ surfaces are depicted in (d), (e), and (f). These are 3 adsorption sites of $\mathrm{Pt}(100), 5$ adsorption sites of $\mathrm{Pt}(110)$, and 4 adsorption sites of $\mathrm{Pt}(111)$ surface.

\section{Computational methods}

Our study on the adsorption of $\mathrm{H}_{2} \mathrm{O}$ on $\mathrm{Pt}$ surfaces is based on DFT [29-30], which is proven accurately in describing a certain part of the system such as catalytic reaction. The computations in this study use the DFT as performed in the VASP [31-34]. The projector augmented wave technique (PAW) [35] is applied to describe the effect of core electrons in the valence electron density. A plane-wave expansion of the valence states with a cut-off energy of $400 \mathrm{eV}$ is used in calculations. Computational accuracy problems arising from electrons exchange and correlation is ensured by the Perdew-Burke-Ernzerhof (PBE) functional $[35,37]$ in the type of generalized gradient approximation (GGA). Brillouin zone numerical integrations are performed on a grid of $5 \times 5 \times 1$ Monkhorst-Pack [38] special k-points and a first order Methfessel-Paxton smearing [39] of width $\sigma=0.2 \mathrm{eV}$. The most stable structure of $\mathrm{H}_{2} \mathrm{O}$ on $\mathrm{Pt}(100), \mathrm{Pt}(110)$, and $\mathrm{Pt}(111)$ are investigated by carefully explore the 


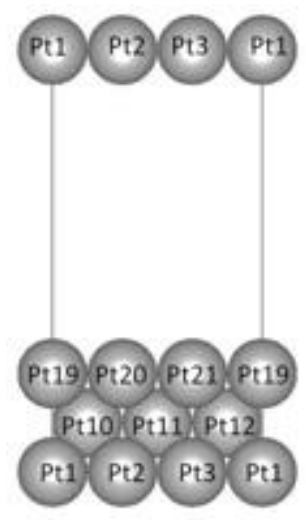

(a)

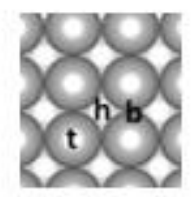

(d)

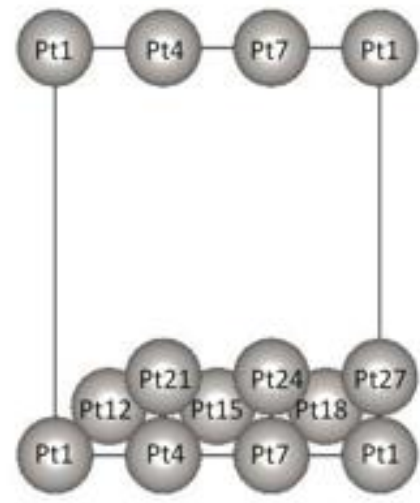

(b)

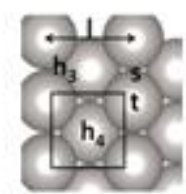

(e)

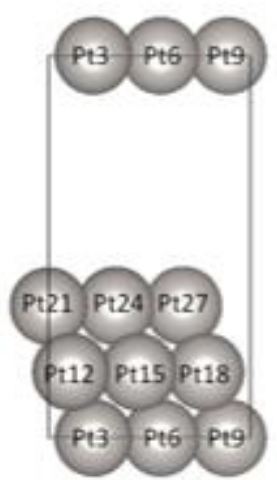

(c)

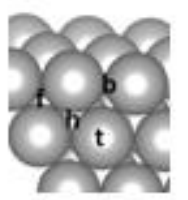

(f)

Fig 1. The side view of surface models of (a) $\mathrm{Pt}(100)$, (b) $\mathrm{Pt}(110)$, and (c) $\mathrm{Pt}(111)$ with vacuum as periodic slabs and the top view of (d) $\mathrm{Pt}(100)$, (e) $\mathrm{Pt}(110)$, and (f) $\mathrm{Pt}(111)$ with related all possible adsorption sites. Top sites are labelled with t, bridge sites are pointed with b, while f, h, h3, h4 for fcc hollow-, hcp hollow-, 3 fold hollow-, and 4 fold hollow- site respectively, whereas $\mathrm{s}$ and I denote short- and long- bridge respectively

potential energy minimum, i.e., by varying the $\mathrm{H}_{2} \mathrm{O}$ atomic position in all directions $(x, y, z)$ at all adsorption sites (see Fig. 1). This is an important method to obtain the most stable structure, which is evaluated in term of binding energies. In addition, the dipole moment corrections [40] are calculated for all systems since the water molecular adsorption is modeled to occur at one slab side.

\section{RESULT AND DISCUSSION}

In the gas phase, the physical structure of the water molecules we obtained from the calculation is a bent structure of triatomic molecule that has an $\mathrm{O}-\mathrm{H}$ bond length of $0.96 \AA$ bond length and $\mathrm{H}-\mathrm{O}-\mathrm{H}$ angle of $104.6^{\circ}$. These results are in excellent agreement with chemistry databases from valence shell electron pair repulsion theory (VSEPR), valence bond theory (VB), and molecular orbital theory (MO). Here, the experimental data from Hasted, 1972 reported that $\mathrm{O}-\mathrm{H}$ bond length and the angle of $\mathrm{H}-\mathrm{O}-\mathrm{H}$ of free $\mathrm{H}_{2} \mathrm{O}$ molecule are $0.96 \AA$ and $104.5^{\circ}$ respectively [41]. Moreover, our calculation on the electronic structure of HOMO-LUMO gap is $8.1 \mathrm{eV}$, which is in the range of experimental values from $7.0 \mathrm{eV}$ [42] to $8.9 \mathrm{eV}$ [43]. Thus, we may conclude that our model of an $\mathrm{H}_{2} \mathrm{O}$ molecule represents the real experimental findings for both structural parameter and electronic structure, as well as the obtained geometrical structure of our surface model in Fig. 1. Thus, from these preliminary calculations we establish the system to model $\mathrm{H}_{2} \mathrm{O}$ adsorption on $\mathrm{Pt}(100), \mathrm{Pt}(110)$, and $\mathrm{Pt}(111)$ surfaces.

An adsorption energy is the simplest parameter to characterize the natural of surface-adsorbate interactions. From the calculated energy one may derive any physical quantities which are required to explain any processes. We define the adsorption energy of $\mathrm{H}_{2} \mathrm{O}$ on $\mathrm{Pt}$ surfaces as $E_{\text {ads }}=E_{\mathrm{Pt}_{1} \mathrm{H}_{2} \mathrm{O}}-\left(\mathrm{E}_{\mathrm{Pt}}+\mathrm{E}_{\mathrm{H}_{2} \mathrm{O}}\right)$, where $E_{\text {ads }}$ represents the adsorption energy, $E_{\mathrm{P}_{\mathrm{t} / \mathrm{H}_{2} \mathrm{O}} \mathrm{O}}$ is total energy of the system, $E_{\mathrm{Pt}}$ means total energy of the bare Pt surface, and $\mathrm{E}_{\mathrm{H}_{2} \mathrm{O}}$ expresses the total energy of free water molecule in the gas phase. Our calculation results are then summarized in Table 1. Here we list the first top three most stable adsorption configuration for each surfaces. Thus we correlate the adsorption energy with observed charge transfer and adsorption structural geometry to explain the nature of adsorption of water on $\mathrm{Pt}$ surfaces. Here, we use the upright water geometry, which is obtained from the optimized structure of all atomic $\mathrm{H}_{2} \mathrm{O}$ relaxation, rather than near parallel orientations. In this case, the choiced geometry is more relevant for our adsorption model, i.e., both all atoms of adsorbate and all atoms of the first two layers in surfaces move freely during interaction resulting in upright configuration as the most stable $\mathrm{H}_{2} \mathrm{O}$ geometry. 
Table 1. Correlation between adsorption energy, structure, and charge transfer in the adsorption of $\mathrm{H}_{2} \mathrm{O}$ on the low index Pt surfaces

\begin{tabular}{cccccc}
\hline Pt(index) & Sites & $\begin{array}{c}E_{\text {ads }} \\
(\mathbf{e V})\end{array}$ & $\begin{array}{c}\text { Pt-O distant } \\
(\AA)\end{array}$ & $\angle$ (H-O-H) & $\begin{array}{c}\text { Total charge } \\
\text { transfer }\left(\mathbf{e}^{-}\right)\end{array}$ \\
\hline \multirow{3}{*}{$\operatorname{Pt}(100)$} & Top & -0.34 & 2.36 & $109.9^{\circ}$ & 0.057 \\
& Bridge & -0.30 & 2.88 & $107.2^{\circ}$ & 0.029 \\
& Hollow & -0.25 & 3.52 & $104.6^{\circ}$ & 0.003 \\
\hline \multirow{3}{*}{$\operatorname{Pt}(110)$} & Top & -0.47 & 2.19 & $107.9^{\circ}$ & 0.055 \\
& Long bridge & -0.22 & 2.91 & $106.4^{\circ}$ & 0.024 \\
& Short bridge & -0.16 & 3.27 & $105.8^{\circ}$ & 0.006 \\
\hline \multirow{3}{*}{$\operatorname{Pt}(111)$} & Top & -0.32 & 2.56 & $109.5^{\circ}$ & 0.026 \\
& Hollow fcc & -0.30 & 3.23 & $106.4^{\circ}$ & 0.015 \\
& Hollow hcp & -0.29 & 3.25 & $104.5^{\circ}$ & 0.013 \\
\hline
\end{tabular}

This upright $\mathrm{H}_{2} \mathrm{O}$ geometry describes the simple electrostatic model, where the Coulomb interactions plays important roles, as also used by Ishikawa et al. [44]. In the electrostatic model, adsorption energetics are dominantly driven by the geometrical structures which is finally determine the atomic and electronic distances in the systems.

Table 1 shows the calculated adsorption energies of $\mathrm{H}_{2} \mathrm{O}$ molecule on the considered $\mathrm{Pt}$ surfaces. In all cases, $\mathrm{H}_{2} \mathrm{O}$ prefers adsorb atop site. On the surface with the same Miller index, it is noted that the adsorption energy increases with the increase in total charge transfer (CT). The CT is calculated from Bader analysis [45], i.e., probability of finding the electronic charge density in the system. We also observed that the interaction strength is also related to the order of $\mathrm{Pt}-\mathrm{O}$ bond distant, where the shorter the bond distant, the stronger the interaction. It is obviously can be understood that Coulomb attraction between positively charged nucleus and nearest electronic systems is stronger at the closer atomic distant. Thus, we may suggest that Coulomb interaction plays an important role in the $\mathrm{H}_{2} \mathrm{O}-\mathrm{Pt}$ interaction, which is the type of attractive interaction that is more dominant in this adsorption configuration than the repulsive interaction type. Since the term most stable configuration for water adsorption on the Pt-surface means that the most preferred site for water is absorbed on the Pt-surface, we will now use the top site of $\mathrm{Pt}(100), \operatorname{Pt}(110)$, and $\mathrm{Pt}(111)$ to discuss the mechanism of water adsorption on the surfaces.

On the Pt surface of (100) Miller index, our results show that $\mathrm{H}_{2} \mathrm{O}$ adsorption preferentially take place atop site with adsorption energy of $-0.34 \mathrm{eV}$ and $\mathrm{Pt}-\mathrm{O}$ bond distant is $2.36 \AA$. These results close to the other DFT calculation, e.g., Fajín et al. [24]. They obtained $-0.43 \mathrm{eV}$ of adsorption energy and $2.37 \AA$ of $\mathrm{Pt}-\mathrm{O}$ bond distant. These discrepancies might be caused by the different type of exchange correlation and the surface model. In their work, they used GGA method with PW91 exchange correlation functional and surface models with the $2 \times 2$ unit cell and a $10 \AA$ of vacuum. Further, our calculation result also shows that the angle of $\mathrm{H}-\mathrm{O}-\mathrm{H}$ widen up to $109.9^{\circ}$ after adsorption. Due to the relatively small absorption energy value, but having considerable geometric structural changes, it can be predicted that the possibility of dissociation of water molecules can occur under conditions such as the presence of promoters. Atop $\operatorname{Pt}(100)$ we also obtained the total charge transfer of $0.058 \mathrm{e}^{-}$from the water molecule to the surface. However, when observed at each directly interacting atom, both $\mathrm{O}$ atom and $\mathrm{Pt}$ atom appear to release charges, i.e., $\mathrm{O}$ releases $0.056 \mathrm{e}^{-}$and $\mathrm{Pt}$ releases $0.143 \mathrm{e}^{-}$and forms a bond. Thus, the visualization of the geometrical structure of water adsorption on Pt surfaces, associated with the charge distribution occurring in the adsorption, is given in Fig. 2.

Next, our result on the geometrical structure of $\mathrm{H}_{2} \mathrm{O}$ on $\mathrm{Pt}(110)$ is illustrated in the Fig. 2(b). This corresponds to the calculated adsorption energy of $0.47 \mathrm{eV}$ with total charge transfer of $0.055 \mathrm{e}^{-}$as listed in the Table 1. Pt-O bond distant at this configuration is $2.19 \AA$, or shorter by $0.17 \AA$ compare to that of $\mathrm{Pt}(100)$ surface. Again, we get also a slight difference with Fajín et al., i.e., $-0.50 \mathrm{eV}$ of adsorption energy and 2.26 $\AA$ of calculated Pt-O bond distant [24], with the same reason for $\mathrm{H}_{2} \mathrm{O} / \mathrm{Pt}(100)$. Then, the result we obtain for the angle of $\mathrm{H}-\mathrm{O}-\mathrm{H}$ after $\mathrm{H}_{2} \mathrm{O}$ interacts with $\mathrm{Pt}(110)$ is $107.9^{\circ}$. When this angle widening is associated with the considerable adsorption energy, one may suggest that the possibility of $\mathrm{H}_{2} \mathrm{O}$ dissociative adsorption on $\mathrm{Pt}$ is higher in (110) Miller index. This suggestion is also supported by the experimental data of $\mathrm{H}_{2} \mathrm{O} / \mathrm{Ni}(110)$ by Hodgson and Haq [46]. Both our calculation and their result have comparable value of adsorption energy. Their experiments show that $\mathrm{H}_{2} \mathrm{O}$ remains almost intact on $\mathrm{Ni}(110)$ up to $200 \mathrm{~K}$ and dissociation occurred above this temperature, as is expected in our model. Moreover, interestingly, we found that adsorption of $\mathrm{H}_{2} \mathrm{O} / \mathrm{Pt}(110)$ is more stable than that of $\mathrm{Pt}(100)$ even though the total charge transfer is larger for the case of $\mathrm{H}_{2} \mathrm{O} / \mathrm{Pt}(100)$. Thus, on closer inspection of the directly interacting atoms, it was found that probability of Oxygen atom releases charge is around $0.054 \mathrm{e}^{-}$while 


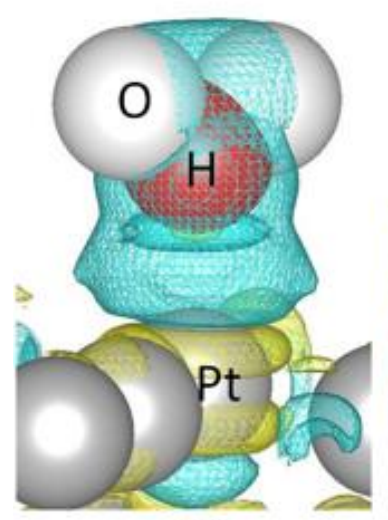

(a)

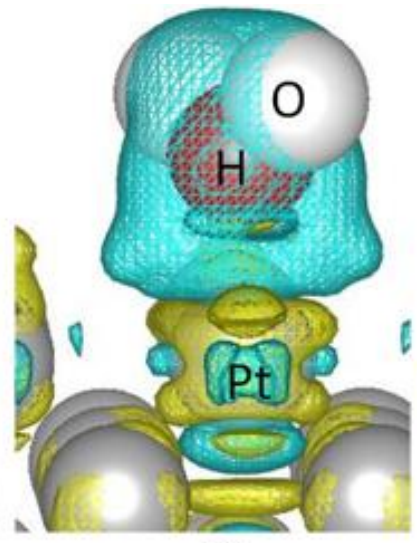

(b)

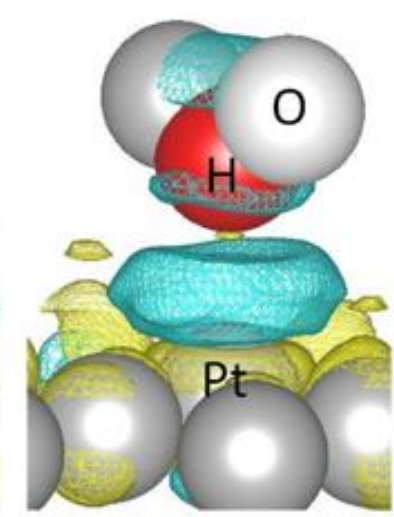

(c)

Fig 2. Charge distribution of $\mathrm{H}_{2} \mathrm{O}$ adsorption on (a) $\mathrm{Pt}(100)$, (b) $\mathrm{Pt}(110)$, and (c) $\mathrm{Pt}(111)$. The yellow color represents charge accumulation while the blue color indicates charge depletion
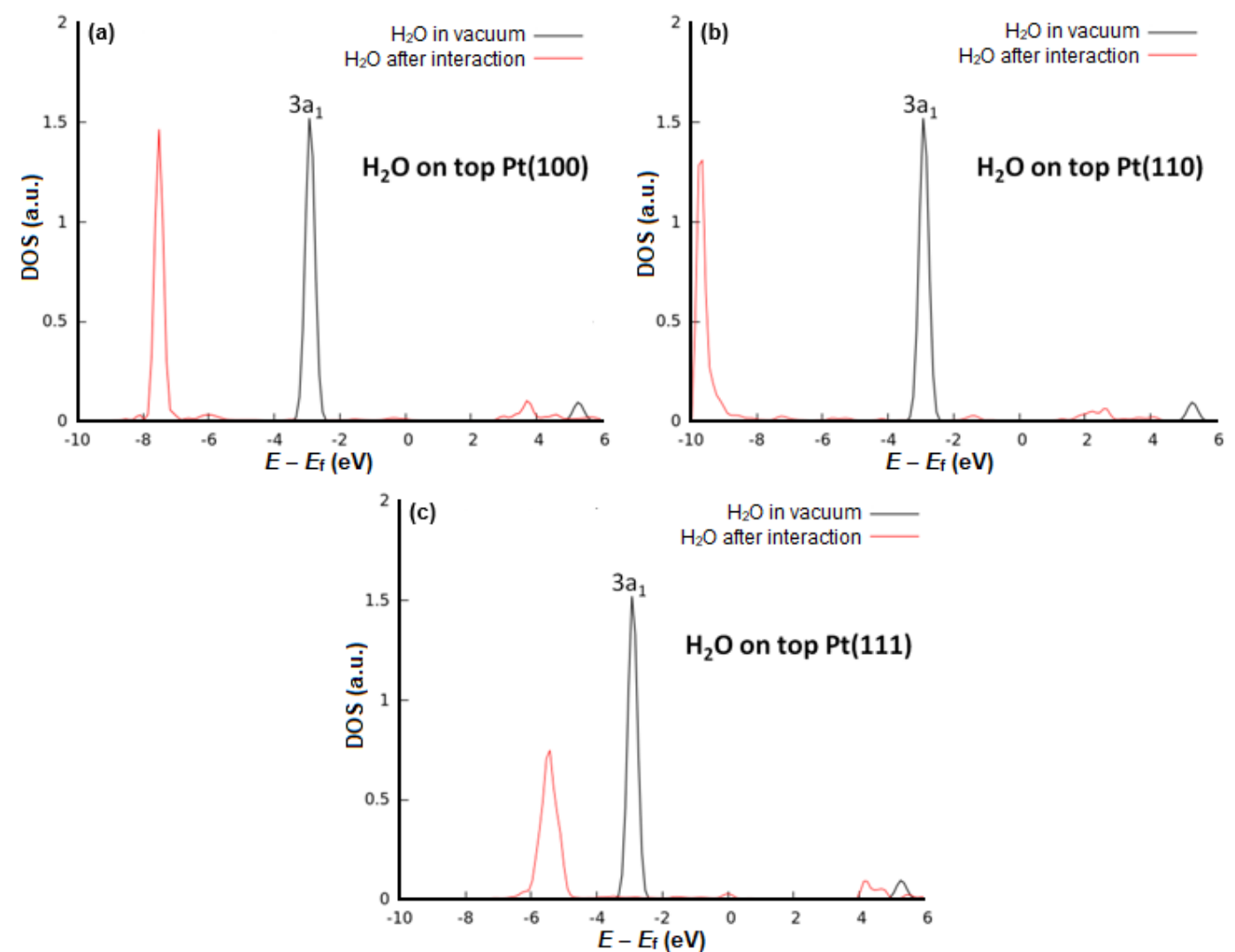

Fig 3. Local Density of States (LDOS) projected on $\mathrm{O}$ of $\mathrm{H}_{2} \mathrm{O}$ before (black line) and after (red line) $\mathrm{H}_{2} \mathrm{O}$ adsorption on (a) $\mathrm{Pt}(100)$, (b) $\mathrm{Pt}(110)$, and (c) $\mathrm{Pt}(111)$

the corresponding Pt-atom is around $0.157 \mathrm{e}$. In other word, the probability of finding charge accumulated at the formed bond is more in the case of $\mathrm{H}_{2} \mathrm{O} / \mathrm{Pt}(110)$ and less for $\mathrm{H}_{2} \mathrm{O} / \mathrm{Pt}(100)$ as described in Fig. 2. Here, at the formed Pt-O bonding, the yellow color in Fig. 2(b) has more intensity, which means that more charge is accumulated in this region than in Fig. 2(a), while the Fig. 2(c) has the least charge at the Pt-O bonding.
In the case of adsorption of $\mathrm{H}_{2} \mathrm{O}$ on $\mathrm{Pt}(111)$, the most preferred site for $\mathrm{H}_{2} \mathrm{O}$ adsorption is on top site as shown in Fig. 2(c). The calculated total charge transfer is $0.026 \mathrm{e}^{-}$with adsorption energy of $\mathrm{E}_{\mathrm{ads}}=-0.32 \mathrm{eV}$ and the $\mathrm{Pt}-\mathrm{O}$ bond length is $0.56 \AA$. These obtained Pt$\mathrm{H}_{2} \mathrm{O}$ bond strength and Pt-O bond length are slightly different with other DFT calculations [24,27]. This may be caused by the different exchange correlation and 
other calculation parameters as well as the model parameters of the surface. Further, the experimental value of adsorption energy of a single water molecule on $\mathrm{Pt}(111)$ could not be provided. Thus, the confirmation of our result to the experiment is connected to the heat of adsorption of $\mathrm{H}_{2} \mathrm{O} / \mathrm{Pt}(111)$ in the multilayer system at $120 \mathrm{~K}$, where formation of amorphous solid water is observed. Here, heat of adsorption, which is defined as the negative of the differential standard molar enthalpy of adsorption of $\mathrm{H}_{2} \mathrm{O}$ on $\mathrm{Pt}(111)$ is $0.489 \mathrm{eV}$ [47]. Using a temperature programmed desorption (TPD) and spectroscopic methods (XPS, UPS), Sexton and Hughes, obtained the adsorption energy of water on $\mathrm{Pt}(111)$ is $0.412 \mathrm{eV}$ [48]. However, for the case of (111) surface index, our result of the atop position as the most preferential adsorption site is in agreement with STM results by Morgenstern et al. [23,49]. The weakest interaction strength of $\mathrm{H}_{2} \mathrm{O} / \mathrm{Pt}(111)$ compared to $\mathrm{Pt}(100)$ and $\mathrm{Pt}(110)$ indicates the most unflavored water dissociation at the $\mathrm{Pt}(111)$ surface. This confirms experiments under UHV conditions stating that water adsorption on $\mathrm{Pt}(111)$ proceed molecularly with no dissociation, as well as observed in ultraviolet photoelectron spectroscopy (UPS) and X-ray photoelectron spectroscopy (XPS) [50]. Supplementary analysis regarding substrate-adsorbate interaction of $\mathrm{H}_{2} \mathrm{O} /$ low index $\mathrm{Pt}$ surfaces is then provided by the electronic density of states in Fig. 3.

Fig. 3 shows the density of states (DOS) projected on atomic $\mathrm{O}$ of $\mathrm{H}_{2} \mathrm{O}$ in the gas phase, i.e., $\mathrm{H}_{2} \mathrm{O}$ before interaction with $\mathrm{Pt}$ (black lines) and atomic $\mathrm{O}$ of $\mathrm{Pt}-\mathrm{H}_{2} \mathrm{O}$ systems, i.e., $\mathrm{H}_{2} \mathrm{O}$ after interaction with $\mathrm{Pt}$ (red lines). It can be seen that the highest occupied molecular orbitals (HOMO) of an upright $\mathrm{H}_{2} \mathrm{O}$, the so-called the $3 \mathrm{a}_{1}$ orbital, loses its peak after $\mathrm{H}_{2} \mathrm{O}$ interact with $\mathrm{Pt}$ surfaces forming two new states. These states called the bonding states, i.e., below the initial $3 a_{1}$ states, and the antibonding states, located at right side relative to the initial states and to the fermi level. In all three surfaces, the bonding states are occupied while antibonding states are empty, showing the upright water interacts through $3 \mathrm{a}_{1}$ orbital. From Fig. 3, it is clear that atop Pt(110), the antibonding states have the lowest intensity implying the most charge contributing to the bond formation, which is located at the far left of bonding states. This is confirmed by the shortest Pt-O bond distant (see Table 1) and the highest yellow intensity of charge accumulation at the bond as depicted in Fig. 2. This also explain why the adsorption energy of $\mathrm{H}_{2} \mathrm{O} / \mathrm{Pt}(110)$ is strongest among three surfaces. For both Fig. 3(a) and (c) have the same antibonding states but different bonding peak's intensity and bonding peak's location. Peak intensity in the bonding states represents the probability of finding charge accumulation, and peak's location corresponds to the stability of systems, i.e., the more to the left the bonding peak's location relative to the Fermi level, the more stable the system. $\mathrm{H}_{2} \mathrm{O} / \mathrm{Pt}(100)$ has higher bonding peak intensity and located more left relative to the Fermi level compared to the case of $\mathrm{H}_{2} \mathrm{O} / \mathrm{Pt}(111)$. Thus, it brings the consequence of higher $\mathrm{H}_{2} \mathrm{O} / \mathrm{Pt}(100)$ interaction strength compared to interaction of $\mathrm{H}_{2} \mathrm{O}$ with the Pt(111) surface.

\section{CONCLUSION}

We conducted periodic DFT calculations to study the $\mathrm{H}_{2} \mathrm{O} / \mathrm{Pt}$ adsorption mechanism, which is evaluated from the adsorption energy of $\mathrm{H}_{2} \mathrm{O}$ on $\mathrm{Pt}(100), \mathrm{Pt}(110)$, and $\mathrm{Pt}(111)$ surfaces and the related charge transfer. The geometric structure of $\mathrm{H}_{2} \mathrm{O}$ on $\mathrm{Pt}$ seems to control the value of the adsorption energy dominantly, since Coulomb interactions are very sensitive to the distance between nuclei, nuclei-electrons, and also to the distance between electrons. For the most stable configuration of $\mathrm{H}_{2} \mathrm{O}$ adsorption on each Pt-surface, i.e., at the top, the bond strength between $\mathrm{H}_{2} \mathrm{O}$ and $\mathrm{Pt}$ follows the order of indices of $\mathrm{Pt}(110)>\mathrm{Pt}(100)>$ $\mathrm{Pt}(111)$. This order follows the charge transfer order, i.e., the more the charge transfer contributing to the bond formations, the stronger the interaction. In addition, another important result for the charge transfer analysis of $\mathrm{H}_{2} \mathrm{O}$ adsorption on the Pt surface with upright $\mathrm{H}_{2} \mathrm{O}$ geometry is that the interaction mechanism occurs through the use of shared electrons, which are released from both $\mathrm{Pt}$ and the $\mathrm{H}_{2} \mathrm{O}$ followed by Pt-O bonding formation. Thus, these results might be used to realize the anode modification for optimizing the DMFC performance since one of the most important processes in DMFC is the water activation. Water activation is in line with adsorption energy, i.e., the stronger the adsorption energy, the more favor the dissociative adsorption.

\section{ACKNOWLEDGEMENT}

Authors would like to thank Neneng A.M. Sari for her contributions in some calculations. WTC acknowledge also the dean of the faculty of Mathematics and Natural Sciences, Universitas Jenderal Soedirman for his permission to use the computational tools during the research.

\section{REFERENCES}

[1] Pirug, G., and Bonzel, H.P., 1999, "Electrochemical Double-Layer Modeling Under Ultrahigh Vacuum Condition" in Interfacial Electrochemistry: Theory, Experiment, and Applications, Wieckowski, A., Eds., Marcel Dekker Inc., New York, 269-286. 
[2] Liu, P., 2013, "Synergistic Effect of Metal/Oxide Catalysts in the Water-Gas Shift Reactions: A Theory-Guided Rotational Design of Better Catalysts" in New and Future Developments in Catalysis: Hybrid Materials, Composites, and Organocatalysts, $1^{\text {st }}$ ed., Suib, S.L., Eds., Elsevier Science Ltd, Elsevier Science \& Technology, Oxford, 213-238.

[3] Talbott, D., 2002, Corrosion Science and Technology, Plenum Publishers, New York, 134.

[4] Bennett, B., Koraishy, B.M., and Meyers, J.P., 2012, Modeling and optimization of the DMFC system: Relating materials properties to system size and performance, J. Power Sources, 218, 268-279.

[5] Kumar, P., Dutta, K., Das, S., and Kundu, P.P., 2014, An overview of unsolved deficiencies of direct methanol fuel cell technology: factors and parameters affecting its widespread use, Int. J. Energy Res., 38 (11), 1367-1390.

[6] Cameron, D.S., Hards, G.A., Harrison, B., and Potter, R.J., 1987, Direct methanol fuel cells: Recent developments in the search for improved performance, Platinum Met. Rev., 31 (4), 173-181.

[7] Moura, A.S., Fajín, J.L.C., Mandado, M., and Cordeiro, M.N.D.S., 2017, Ruthenium-platinum catalysts and direct methanol fuel cells (DMFC): A review of theoretical and experimental breakthroughs, Catalysts, 7 (2), 47.

[8] Kakati, N., Maiti, J., Lee, S.H., Jee, S.H., Viswanathan, B., and Yoon, Y.S., 2014, Anode catalysts for direct methanol fuel cells in acidic media: Do we have any alternative for $\mathrm{Pt}$ or $\mathrm{Pt}-\mathrm{Ru}$, Chem. Rev., 114 (24), 12397-12429.

[9] Chang, J., Feng, L., Jiang, K., Xue, H., Cai, W.B., Liu, C., and Xing, W., 2016, Pt-CoP/C as an alternative $\mathrm{PtRu} / \mathrm{C}$ catalyst for direct methanol fuel cells, J. Matter. Chem. A, 4 (47), 18607-18613.

[10] Khan, I.A., Qian, Y., Badshah, A., Zhao, D., and Nadeem, M.A., 2016, Fabrication of highly stable and efficient $\mathrm{PtCu}$ alloy nanoparticles on highly porous carbon for direct methanol fuel cells, ACS Appl. Mater. Interfaces, 8 (32), 20793-20801.

[11] Ugalde-Reyes, O., Hernández-Maya, R., OcampoFlores, A. L., Alvarez-Ramírez, F., SosaHernández, E., Angeles-Chavez, C., and Roquero, P., 2015, Study of the electrochemical activities of Mo-modified Pt catalysts, for application as anodes in direct methanol fuel cells: Effect of the aggregation route, J. Electrochem. Soc., 162 (3), 132-141.

[12] Kim, J., Jang, J.S., Peck, D.H., Lee, B., Yoon, S.H., and Jung, D.H., 2016, Methanol-tolerant platinumpalladium catalyst supported on nitrogen-doped carbon nanofiber for high concentration direct methanol fuel cells, Nanomaterials, 6 (8), 148.
[13] Neto, A.O., Franco, E.G., Aricó, E., Linardi, M., and Gonzalez, E.R., 2003, Electro-oxidation of methanol and ethanol on Pt-Ru/C and Pt-RuMo/C electrocatalysts prepared by Bönnemann's method, J. Eur. Ceram. Soc., 23 (15), 2987-2992.

[14] Gurau, B., Viswanathan, R., Liu, R., Lafrenz, T.J., Ley, K.L., Smotkin, E.S., Reddington, R., Sapienza, A., Chan, B.C., Mallouk, T.E., and Sarangapani, S., 1998, Structural and electrochemical characterization of binary, ternary, and quaternary platinum alloy catalysts for methanol electro-oxidation, J. Phys. Chem. B, 102 (49), 9997-10003.

[15] Thiel, P.A., and Madey, T.E., 1987, The interaction of water with solid-surfaces: Fundamental aspects, Surf. Sci. Rep., 7 (6-8), 211-385.

[16] Henderson, M.A., 2002, The interaction of water with solid surfaces: fundamental aspects, Surf. Sci. Rep., 46, 5-308.

[17] Cahyanto, W.T., Widanarto, W., Shukri, G., and Kasai, H., 2016, Theoretical studies of the Adsorption of hydroxymethylidyne $(\mathrm{COH})$ on Ptalloy surfaces using density functional theory, Phys. Scr., 91 (2), 6.

[18] Cahyanto, W.T., 2014, Adsorption mechanism of carbon monoxide on PtRu and PtRuMo surfaces in the density functional theory perspective, $A d v$. Mater. Res., 896, 537-540.

[19] Cahyanto, W.T., Shukri, G., Agusta, M.K., and Kasai, H., 2013, Adsorption of formaldehyde and formyl intermediates on Pt, PtRu-, and PtRuMoalloy surfaces: A density functional study, Appl. Surf. Sci., 266, 405-409.

[20] Cahyanto, W.T., Padama, A.A.B., Escaño, M.C.S., and Kasai, H., 2012, Preferential sites for adsorption of methanol and methoxy on $\mathrm{Pt}$ and $\mathrm{Pt}-$ alloy surfaces, Phys. Scr., 85 (1), 6.

[21] Anderson, A.B., 1981, Reactions and structures of water and oxygen covered $\mathrm{Pt}(111)$ and $\mathrm{Fe}(100)$, Surf. Sci., 105 (1), 159-176.

[22] Haq, S., Harnett, J., and Hodgson, A., 2002, Growth of thin crystalline ice films on $\mathrm{Pt}(111)$, Surf. Sci., 505, 171-182.

[23] Morgenstern, M., Michely, T., and Comsa, G., 1996, Anisotropy in the adsorption of $\mathrm{H}_{2} \mathrm{O}$ at low coordination sites on Pt(111), Phys. Rev. Lett., 77 (4), 703-706.

[24] Fajín, J.L.C., Cordeiro, M.N.D.S., and Gomes, J.R.B., 2014, Density functional theory study of the water dissociation on platinum surfaces: General trends, J. Phys. Chem. A, 118 (31), 5832-5840.

[25] Li, R., Wang, L., Yue, Q., Li, H., Xu, S., and Liu, J., 2014, Insights into the adsorption of oxygen and water on low-index $\mathrm{Pt}$ surfaces by molecular 
dynamics simulations, New J. Chem., 38 (2), 683692.

[26] Árnadóttir, L., Stuve, E.M., and Jónsson, H., 2010, Adsorption of water monomer and clusters on platinum(111) terrace and related steps and kinks I. Configurations, energies, and hydrogen bonding, Surf. Sci., 604 (21-22), 1978-1986.

[27] Meng, S., Wang, E.G., and Gao, S., 2004, Water adsorption on metal surfaces: A general picture from density functional theory studies, Phys. Rev. B, 69 (19), 195404-195417.

[28] Branger, V., Pelosin, V., Badawi, K.F., and Goudeau, P., 1996, Study of the mechanical and microstructural state of platinum thin films, Thin Solid Films, 275 (1-2), 22-24.

[29] Hohenberg, P., and Kohn, W., 1964, Inhomogeneous electron gas, Phys. Rev., 136 (3B), 864-871.

[30] Kohn W., Sham L.J., 1965, Self-Consistent Equations Including Exchange and correlation Effects, Phys. Rev., 140 (4), 1133-1138.

[31] Kresse, G., and Hafner, J., 1993, Ab initio molecular dynamics for liquid metals, Phys. Rev. B, 47 (1), 558-561.

[32] Kresse, G., and Hafner, J., 1994, $A b$ initio molecular-dynamics simulation of the liquid-metalamorphous-semiconductor transition in germanium, Phys. Rev. B, 49 (20), 14251-14269.

[33] Kresse, G., and Furthmüller, J., 1996, Efficient iterative schemes for $a b$ initio total-energy calculations using a plane-wave basis set, Phys. Rev. B, 54 (16), 11169-11186.

[34] Kresse, G., and Furthmüller, J., 1996, Efficiency of ab-initio total energy calculations for metals and semiconductors using a plane-wave basis set, Comput. Mater. Sci., 6 (1), 15-50.

[35] Kresse, G., and Joubert, D., 1999, From ultrasoft pseudopotentials to the projector augmented-wave method, Phys. Rev. B, 59 (3), 1758-1775.

[36] Perdew, J.P., Chevary, J.A., Vosko, S.H., Jackson, K.A., Pederson, M.R., Singh, D.J., and Fiolhais, C., 1992, Atoms, molecules, solids, and surfaces: Applications of the generalized gradient approximation for exchange and correlation, Phys. Rev. B, 46 (11), 6671-6687.

[37] Perdew, J.P., Burke, K., and Ernzerhof, M., 1996, Generalized gradient approximation made simple, Phys. Rev. Lett., 77 (18), 3865-3868.
[38] Monkhorst, H.J., and Pack, J.D., 1976, Special points for Brillouin-zone integrations, Phys. Rev. B, 13 (12), 5188-5192.

[39] Methfessel, M., and Paxton, A.T., 1989, Highprecision sampling for Brillouin-zone integration in metals, Phys. Rev. B, 40 (6), 3616-3621.

[40] Bengtsson, L., 1999, Dipole correction for surface supercell calculations, Phys. Rev. B, 59 (19), 12301-12304.

[41] Hasted, J.B., 1972, "Liquid Water: Dielectric Properties" in The Physics and Physical Chemistry of Water. Water (A Comprehensive Treatise), Franks, F., Eds., vol. 1, Springer, Boston, MA, 255-309.

[42] Grand, D., Bernas, A., and Amouyal, E., 1979, Photoionization of aqueous indole; Conduction band edge and energy gap in liquid water, Chem. Phys., 44 (1), 73-79.

[43] Goulet, T., Bernas, A., Ferradini, C., and JayGerin, J.P., 1990, On the electronic structure of liquid water: Conduction-band tail revealed by photoionization data, Chem. Phys. Lett., 170 (5-6), 492-496.

[44] Ishikawa, Y., Liao, M.S., and Cabrera, C.R., 2000, Oxidation of methanol on platinum, ruthenium and mixed Pt-M metals ( $M=R u, S n)$ : A theoretical study, Surf. Sci., 463 (1), 66-80.

[45] Bader, R.F.W., 1990, Atoms in Molecules: A Quantum Theory, Oxford University Press, New York.

[46] Hodgson, A., and Haq, S., 2009, Water adsorption and the wetting of metal surfaces, Surf. Sci. Rep., 64 (9), 381-451.

[47] Lew, W., Crowe, M.C., Karp, E., and Campbell, C.T., 2011, Energy of molecularly adsorbed water on clean $\mathrm{Pt}(111)$ and $\mathrm{Pt}(111)$ with coadsorbed oxygen by calorimetry, J. Phys. Chem. C, 115 (18), 9164-9170.

[48] Sexton, B.A., and Hughes, A.E., 1984, A comparison of weak molecular adsorption of organic molecules on clean copper and platinum surfaces, Surf. Sci., 140 (1), 227-248.

[49] Morgenstern, M., Müller, J., Michely, T., and Comsa, G., 1997, The ice bilayer on Pt(111): Nucleation, structure and melting, $Z$. Phys. Chem., 198 (1-2), 43-72.

[50] Fisher, G.B., and Gland, J.L., 1980, The interaction of water with the $\mathrm{Pt}(111)$ surface, Surf. Sci., 94 (2-3), 446-455. 